\title{
Evaluation of reproductive and economic outcomes of dairy heifers inseminated at induced estrus or at fixed time after a 5-day or 7-day progesterone insert-based ovulation synchronization protocol
}

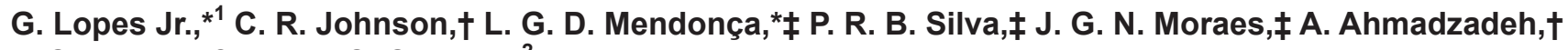 \\ J. C. Dalton, $† \S$ and R. C. Chebel ${ }^{*} \ddagger^{2}$ \\ *School of Veterinary Medicine, University of California, Davis 95616 \\ †Animal and Veterinary Science Department, University of Idaho, Moscow 83844 \\ $\ddagger$ Department of Veterinary Population Medicine, University of Minnesota, St. Paul 55108 \\ §University of Idaho Extension, Caldwell 83605
}

\begin{abstract}
The objectives of the current experiment were to evaluate the reproductive performance and economic outcome of 3 synchronization strategies for first artificial insemination (AI) of dairy heifers. Holstein heifers from 2 herds (site A, California, $\mathrm{n}=415$; site B, Idaho, $\mathrm{n}=425)$ were assigned to 1 of 3 treatments. Heifers assigned to the AI on estrus (AIE) treatment received an injection of $25 \mathrm{mg}$ of $\mathrm{PGF}_{2 \alpha}$ at enrollment $(\mathrm{d} 0)$ and every $11 \mathrm{~d}$ thereafter until AI occurred. Heifers assigned to the CIDR5 treatment received a controlled internal drug release insert (CIDR) containing $1.38 \mathrm{~g}$ of progesterone, which was removed 5 d later concomitantly with an injection of $25 \mathrm{mg}$ of $\mathrm{PGF}_{2 \alpha}$, and received fixedtime AI (TAI) concomitantly with an injection of 100 $\mu \mathrm{g}$ of GnRH 53 to $60 \mathrm{~h}$ later. Heifers assigned to the CIDR7 treatment received a CIDR insert, which was removed $7 \mathrm{~d}$ later concomitantly with an injection of 25 mg of $\mathrm{PGF}_{2 \alpha}$, and received TAI concomitantly with an injection of $100 \mu \mathrm{g}$ of GnRH 53 to $60 \mathrm{~h}$ later. Heifers were observed for estrus and inseminated up to 98 and $73 \mathrm{~d}$ after enrollment in sites A and B, respectively. Thereafter, heifers were moved to pens with bulls and considered failure to conceive to AI if still not pregnant at the end of the observation period. Economic outcomes were based on cost of synchronization protocol (CIDR treatment $=\$ 11, \mathrm{PGF}_{2 \alpha}$ or $\mathrm{GnRH}$ treatments $=\$ 2.5 /$ treatment, estrous detection $=\$ 0.80 /$ heifer per day), rearing cost $(\$ 2.75 /$ heifer per day), and economic loss if a heifer did not conceive to first AI (\$150). Input cost of the reproductive programs $=$ synchronization protocol cost + semen cost + rearing cost + replacement cost. Pregnancy per AI $(\mathrm{P} / \mathrm{AI}) 38 \pm 3$ d after
\end{abstract}

\footnotetext{
Received July 23, 2012.

Accepted November 9, 2012.

${ }^{1}$ Current address: Accelerated Genetics, E10890 Penny Lane, Baraboo, WI 53913.

${ }^{2}$ Corresponding author: chebe002@umn.edu
}

first AI was greatest for AIE heifers (61.1\%) followed by CIDR5 $(44.8 \%)$ and CIDR7 $(35.7 \%)$ heifers. Furthermore, $\mathrm{P} / \mathrm{AI} 73 \pm 7 \mathrm{~d}$ after first $\mathrm{AI}$ was greatest for AIE $(58.8 \%)$ and tended to be greater for CIDR5 (42\%) than for CIDR7 (34.1\%) heifers. The percentage of heifers that had spontaneous luteolysis from CIDR insertion to CIDR removal was reduced for CIDR5 compared with CIDR7 (13.8 vs $31.8 \%$ ). Pregnancy rate was greatest for AIE heifers but did not differ between CIDR5 [adjusted hazard ratio (95\% confidence interval $)=0.75(0.63,0.90)]$ and CIDR7 [adjusted hazard ratio $(95 \%$ confidence interval $)=0.65(0.54,0.77)]$ heifers. Consequently, rearing cost and input cost of AIE heifers $(\$ 67.1 \pm 4.4$ and $-\$ 107.1 \pm 7.0$, respectively) were reduced compared with CIDR5 (\$86.9 \pm 5.1 and $-\$ 143.4 \pm 8.1$, respectively) and CIDR7 (\$98.3 \pm 5.1 and $-\$ 156.5 \pm 8.2$, respectively) heifers, but no differences were observed between CIDR5 and CIDR7 heifers.

Key words: dairy heifer, estrus synchronization, timed artificial insemination

\section{INTRODUCTION}

Reproductive management of dairy heifers does not typically make use of hormones. According to the National Animal Health Monitoring System Part IV published in 2007 (NAHMS, 2007), only 7 and $16.3 \%$ of dairy operations used any hormones for synchronization of the estrous cycle of heifers for first and subsequent AI, respectively. Furthermore, among these herds, approximately $65 \%$ use only $\mathrm{PGF}_{2 \alpha}$ injections to induce estrus (NAHMS, 2007). The reduced adoption of ovulation synchronization protocols for fixed-time AI programs in heifers compared with lactating dairy cows is likely a consequence of the acceptable estrus detection rates observed in dairy heifers (Chebel et al., 2007; Stevenson et al., 2008) and the reduced likelihood of pregnancy following timed AI (TAI) in heifers 
compared with insemination based on signs of estrus (Stevenson et al., 2008). Nonetheless, it is surprising that less than $15 \%$ of dairy herds use $\mathrm{PGF}_{2 \alpha}$-based estrus synchronization protocols for first insemination of heifers (NAHMS, 2007). Estrus-synchronization protocols based on $\mathrm{PGF}_{2 \alpha}$ are low cost and result in reduced interval to first AI, similar pregnancy per AI (P/AI), and improved economic return compared with insemination on spontaneous estrus (Stevenson et al., 2008).

Even though it is not exactly clear why TAI protocols do not result in acceptable $\mathrm{P} / \mathrm{AI}$ in dairy heifers, the fact that a large percentage of heifers have more than 2 follicular waves during the estrous cycle (Sartori et al., 2004) may limit the capacity of TAI protocols to control follicle turnover and recruitment of new follicular waves, steps that are critical for acceptable P/ AI following TAI (Vasconcelos et al., 1999; Cerri et al., 2009). Recently, however, researchers have demonstrated that heifers receiving TAI following 5-d controlled internal drug release (CIDR)-based synchronization protocols had P/AI of approximately 55\% (Rabaglino et al., 2010; Lima et al., 2011). Similarly, beef heifers submitted to a CIDR-based TAI protocol tended to have improved $\mathrm{P} / \mathrm{AI}$ when the length of CIDR treatment was reduced from 7 to $5 \mathrm{~d}$ (Ahmadzadeh et al., 2010). These results are considerably better than those observed when heifers were submitted to the Ovsynch protocol (Schmitt et al., 1996; Pursley et al., 1997; Stevenson et al., 2008) and variations of the Ovsynch protocol (Rivera et al., 2004, 2005, 2006). The greater $\mathrm{P} / \mathrm{AI}$ observed with the 5-d CIDR protocol may result in greater adoption of TAI protocols for heifers, particularly in herds with inadequate facilities for daily estrus observation of heifers or herds that are too small and have a very small number of replacement heifers, making daily estrus detection inefficient. The studies with dairy heifers published to date evaluating the 5 -d CIDR-based synchronization protocols, however, have not compared the $\mathrm{P} / \mathrm{AI}$ of heifers submitted to the 5 -d CIDR-based synchronization protocol to that of heifers inseminated on $\mathrm{PGF}_{2 \alpha}$-induced estrus, which has been reported to be between 62 and $65 \%$ (Chebel et al., 2007; Stevenson et al., 2008). Furthermore, considering the significant cost associated with such CIDR-based protocols, it is necessary to compare such protocols with reproductive management strategies that are known to result in good $\mathrm{P} / \mathrm{AI}$ without the added expense, such as protocols based on $\mathrm{PGF}_{2 \alpha}$-induced estrus.

The hypothesis of the current experiment was that heifers inseminated following $\mathrm{PGF}_{2 \alpha}$-induced estrus signs would be more likely to become pregnant than heifers submitted to timed AI after CIDR-based synchronization protocols differing in progesterone $(\mathbf{P} 4)$ treatment length. Furthermore, we hypothesized that extending P4 treatment from 5 to $7 \mathrm{~d}$ would reduce likelihood of pregnancy following TAI. Finally, we hypothesized that heifers submitted to a $\mathrm{PGF}_{2 \alpha}$-based synchronization protocol for first AI would have a greater economic return after a 73- to 98-d breeding period. The objectives of the current experiment were to compare reproductive performance of dairy heifers submitted to a $\mathrm{PGF}_{2 \alpha}$-based estrus detection synchronization protocol with that of heifers submitted to CIDR-based TAI protocols differing in length of $\mathrm{P} 4$ treatment. Another objective of the current experiment was to compare the economic outcomes after a 73- to 98-d breeding period of the different synchronization protocols used for first AI.

\section{MATERIALS AND M ETHODS}

\section{Animals, Housing, and Diets}

This experiment was conducted from October 2007 to July 2008. Holstein heifers from 2 herds, 1 located in the San Joaquin Valley of California (site A, n = 415) and 1 located in the Treasure Valley of Idaho (site B, $\mathrm{n}=425$ ), were used. Heifers were enrolled in the study when they were deemed suitable for first AI, based on withers height (120 to $130 \mathrm{~cm}$, site A) or BW (350 to $380 \mathrm{~kg}$, site B), and moved to a breeding pen. Heifers were housed in open lot corrals with self-locking head stanchions and a back fence to contain heifers. In site A, approximately 150 heifers were housed per corral and in site B, approximately 180 heifers were housed per corral. Heifers were fed a TMR once a day to meet the NRC requirements (NRC, 2001) for Holstein heifers weighing 380 to $400 \mathrm{~kg}$ and gaining 0.6 to $0.8 \mathrm{~kg} / \mathrm{d}$ of BW.

\section{Treatments}

In site $\mathrm{A}$, heifers were randomly assigned to 1 of 3 synchronization treatments; in site $\mathrm{B}$, heifers were assigned to 1 of 3 synchronization treatments in a ratio of 2:1:1 to avoid an excessive number of inseminations on the same day to comply with management practices. Before arrival of heifers on the farm, a list of heifers eligible to be enrolled in the study was generated by study personnel using Dairy Comp 305 (Valley Ag Software, Tulare, CA) and copied to an Excel spreadsheet (Microsoft Corp., Redmond, WA). Treatments were randomly determined using pieces of paper with the treatment codes (site A: AIE, CIDR5, and CIDR7; and, site B: AIE, AIE, CIDR5, and CIDR7), as defined below.

Treatments are depicted in Figure 1. Heifers enrolled in the $\mathrm{AI}$ in estrus (AIE, $\mathrm{n}=338$ ) treatment received 
$\mathrm{PGF}_{2 \alpha}$ (25 mg of dinoprost tromethamine; Lutalyse, Pfizer Animal Health, Madison, NJ) injections every $11 \mathrm{~d}$ until inseminated or until they were removed from the study and censored. Heifers enrolled in the CIDR5 $(\mathrm{n}=250)$ synchronization protocol received a CIDR insert (1.38 g of P4; Eazi-Breed CIDR, Pfizer Animal Health) for $5 \mathrm{~d}$; upon CIDR removal, heifers received a $\mathrm{PGF}_{2 \alpha}$ injection; and 53 to $60 \mathrm{~h}$ after the $\mathrm{PGF}_{2 \alpha}$ injection, heifers received a $\mathrm{GnRH}$ injection $(100 \mu \mathrm{g}$ of gonadorelin diacetate; Cystorelin, Merial Ltd., Duluth, GA) concomitant with fixed-time AI. Heifers enrolled in the CIDR7 ( $\mathrm{n}=252)$ synchronization protocol received a CIDR insert for $7 \mathrm{~d}$; upon CIDR removal, heifers received a $\mathrm{PGF}_{2 \alpha}$ injection; and 53 to $60 \mathrm{~h}$ after the $\mathrm{PGF}_{2 \alpha}$ injection, heifers received a $\mathrm{GnRH}$ injection concomitant with fixed-time AI. After the first AI, heifers from all treatments were re-inseminated on the same day of observed estrus.

Determination of when heifers were moved to a pen with bulls was made by herd personnel who were blinded to treatments, taking into consideration the number of inseminations a heifer had received and the necessity for space in the breeding pens. In site A, the interval from enrollment in the study to entering the pen with bulls was $98 \mathrm{~d}$ and, in site $\mathrm{B}$, the median interval from enrollment to entering the pen with bulls was $73 \mathrm{~d}$ (range $=71$ to 81 ).

\section{Estrus Detection and Al}

Heifers were observed daily in the morning for signs of behavioral estrus and signs of estrus based on removal of tail paint (All-Weather Paintstick, LA-CO Industries, Chicago, IL). Within each site, 2 technicians that were blinded to treatments diagnosed estrous and inseminated heifers. Semen from 4 sires was used in site A and semen from 5 sires was used in site B.

\section{Blood Samples}

Blood was sampled on d 0 from a sub-group of heifers at site $\mathrm{A}(\mathrm{AIE}=132, \mathrm{CIDR} 5=129$, and CIDR7 $=123)$ and site B (CIDR5 $=102$ and CIDR7 $=97)$. Furthermore, blood was sampled from a sub-group of heifers at site A on the day of CIDR removal (30 min after CIDR removal) and on the day of TAI (CIDR5 = 139 and CIDR7 = 135). At site B, blood was sampled from a sub-group of heifers on the day of timed AI $($ CIDR5 $=89$ and CIDR7 $=66)$. Heifers from which blood was sampled were selected randomly. Differences
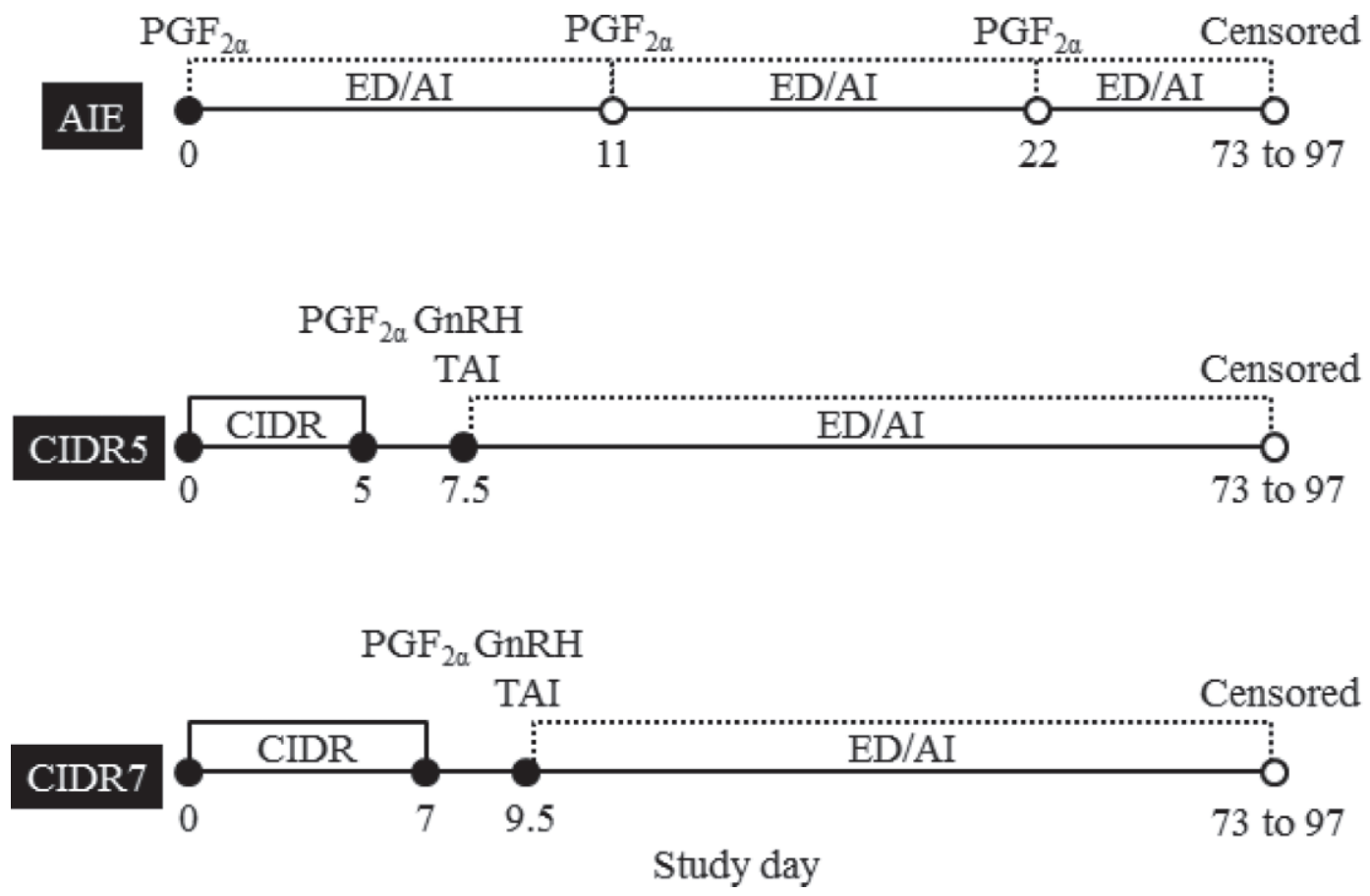

Figure 1. Diagram of activities and treatments. Closed circles $(\bullet)=$ blood sample; AIE $=$ AI at estrus; CIDR $=$ controlled internal drug release insert containing $1.38 \mathrm{~g}$ of progesterone (Eazi-Breed CIDR, Pfizer Animal Health, Madison, NJ); ED = estrus detection; GnRH = i.m. injection of $100 \mu \mathrm{g}$ of gonadrelin diacetate tetrahydrate (Cystorelin, Merial Animal Health, Duluth, GA); PGF $2 \alpha=1 . m$. injection of 25 mg of dinoprost tromethamine (Lutalyse, Pfizer Animal Health); and TAI = timed AI. 
in numbers of heifers sampled in site A and B was due to personnel availability at the different sites.

Blood was sampled $(7 \mathrm{~mL})$ from the median coccygeal vein or artery using evacuated tubes (Becton Dickinson, Franklin Lakes, NJ) containing Na EDTA. Samples were immediately placed in ice and transported to the laboratory within $5 \mathrm{~h}$ of collection. Blood tubes were centrifuged at $2,000 \times g$ for 15 min for plasma separation. Plasma samples were frozen at $-25^{\circ} \mathrm{C}$ and later analyzed for P4 concentration by RIA (Coat-a-Count Progesterone, Siemens Medical Solutions Diagnostics, Los Angeles, CA).

Heifers from all treatments were classified based on $\mathrm{P} 4$ concentration $(\mathrm{P} 4<1 \mathrm{ng} / \mathrm{mL}$ or $\mathrm{P} 4 \geq 1 \mathrm{ng} / \mathrm{mL})$ on d 0 , and CIDR5 and CIDR7 heifers were classified based on $\mathrm{P} 4$ concentration $(\mathrm{P} 4<1 \mathrm{ng} / \mathrm{mL}$ or $\mathrm{P} 4 \geq 1 \mathrm{ng} / \mathrm{mL}$ ) on the day of CIDR removal and on the day of TAI. Heifers were considered to have had luteolysis between the day of CIDR insertion and the day of CIDR removal when $\mathrm{P} 4 \geq 1 \mathrm{ng} / \mathrm{mL}$ on the day of CIDR insertion and $\mathrm{P} 4<1 \mathrm{ng} / \mathrm{mL}$ on the day of CIDR removal. Similarly, heifers were considered to have had luteolysis between the day of CIDR removal and the day of timed AI when $\mathrm{P} 4 \geq 1 \mathrm{ng} / \mathrm{mL}$ on the day of CIDR removal and $\mathrm{P} 4<1$ $\mathrm{ng} / \mathrm{ml}$ on the day of TAI.

\section{Pregnancy Diagnosis and Calculation of Reproductive Performance}

Heifers were diagnosed for pregnancy at $38 \pm 3 \mathrm{~d}$ after AI by manual palpation per rectum of uterine contents. Heifers diagnosed pregnant were re-examined at $73 \pm 7 \mathrm{~d}$ after $\mathrm{AI}$ by manual palpation per rectum of uterine contents. Pregnancy per AI (P/AI) was calculated by dividing the number of heifers pregnant by the number of heifers inseminated, and pregnancy loss after first AI was calculated by dividing the number of heifers diagnosed not pregnant at $73 \pm 7 \mathrm{~d}$ by the number of heifers diagnosed pregnant at $38 \pm 3 \mathrm{~d}$ after first AI. To determine whether treatments affected the pattern of return to estrus of heifers that did not conceive to the first AI, heifers were classified based on interval between first and second AI as having had an altered pattern of return to estrus if they were re-inseminated $<18 \mathrm{~d}$ or $>24 \mathrm{~d}$ after the first AI.

\section{Economic Analysis}

To conduct the economic analysis of the different treatments, we calculated the cost of the synchronization protocols, cost of rearing heifers from enrollment in the study to establishment of pregnancy or removal from the study, and cost of replacing heifers that had not established a pregnancy by the time they were moved to a pen with bulls in which no daily observation for estrus was performed.

The following parameters were used in the economic analysis and they were based on personal communication with the owner and managers of sites $\mathrm{A}$ and $\mathrm{B}$ : cost of CIDR treatment $=\$ 11$, cost of $\mathrm{PGF}_{2 \alpha}$ or GnRH treatments $=\$ 2.50 /$ treatment, estrus detection $=\$ 0.80 /$ heifer per day, rearing cost $=\$ 2.75 /$ heifer per day, economic loss if a heifer did not conceive to first $\mathrm{AI}=\$ 150$. The treatment costs associated with CIDR, $\mathrm{PGF}_{2 \alpha}$, and $\mathrm{GnRH}$ treatments included labor. The cost of estrus detection $(\$ 20 / \mathrm{h}$ according to personal communication; $30 \mathrm{~s} /$ heifer per day according to observation at the collaborating herds) was included for the first $9 \mathrm{~d}$ of the synchronization protocol of AIE heifers because during this period CIDR5 and CIDR7 heifers would not need to be observed for estrus and, after first AI, heifers from all treatments would be observed for estrus. Thus, the added cost due to estrus detection would only be observed in the first $9 \mathrm{~d}$ of the AIE treatment compared with CIDR5 and CIDR7 treatments. The economic loss of heifers that did not conceive to AI before being moved to a pen with bulls is based on findings from Chebel et al. (2010).

\section{Study Design and Statistical Analysis}

The study was designed as a completely randomized design with 3 treatments. A sample size of 250 experimental units per treatment was expected to provide enough replicates to detect statistical significance with an 8-percentage-unit difference in $\mathrm{P} / \mathrm{AI}$ at $38 \pm 3 \mathrm{~d}$ after TAI, when the percentage of AIE heifers pregnant after first AI ranges from 50 to $60 \%(\alpha=0.05 ; \beta=$ 0.20 ; one-tailed test).

Dichotomous data were analyzed by logistic regression using the GLIMMIX procedure of SAS, version 9.3 (SAS/STAT, SAS Institute Inc., Cary, NC), with a binary distribution. Continuous data were analyzed by ANOVA using the MIXED procedure of SAS. Variables with $P>0.10$ were removed until only variables with $P$ $\leq 0.10$ remained in the model. Treatment (AIE vs. CIDR5 vs. CIDR7) was forced in all models and site was used as a random factor with heifers nested within site. To determine the effects of $\mathrm{P} 4$ concentration on $\mathrm{d}$ 0 on probability of pregnancy, treatment (CIDR5 vs. CIDR7), P4 concentration [first as a continuous variable and then as classificatory variable $(\mathrm{P} 4 \geq 1 \mathrm{ng} / \mathrm{mL}$ vs. $\mathrm{P} 4<1 \mathrm{ng} / \mathrm{mL}$ )], and the interaction between treatment and P4 concentration were included in the model. Control heifers were not used in this analysis because the interval from enrollment to first AI varied considerably ( 2 to $98 \mathrm{~d}$ ). The probability of pregnancy at $38 \pm$ $3 \mathrm{~d}$ after AI according to $\mathrm{P} 4$ concentration on $\mathrm{d} 0$ was 
Table 1. Reproductive parameters of heifers submitted to $\mathrm{PGF}_{2 \alpha}$-based (AIE) and CIDR-based (CIDR5 and CIDR7) synchronization protocols ${ }^{1}$

\begin{tabular}{|c|c|c|c|c|}
\hline Item & AIE & CIDR5 & CIDR7 & $P$-value \\
\hline Heifers pregnant $38 \pm 3 \mathrm{~d}$ after first AI ( $\%$, no. in parentheses) & $61.1^{\mathrm{a}}(337)$ & $44.8^{\mathrm{b}}(250)$ & $35.7^{\mathrm{c}}(252)$ & $<0.01$ \\
\hline Heifers pregnant at $73 \pm 7$ to first AI ( $\%$, no. in parentheses) & $58.8^{\mathrm{a}}(337)$ & $42.0^{\mathrm{b}, \mathrm{A}}(250)$ & $34.1^{\mathrm{b}, \mathrm{B}}(252)$ & $<0.01$ \\
\hline Interval $(\mathrm{d})$ between first and second $\mathrm{AI}( \pm \mathrm{SEM})$ & $25.7 \pm 1.0$ & $22.7 \pm 1.0$ & $24.6 \pm 0.9$ & 0.11 \\
\hline Heifers pregnant to second AI (\%, no. in parentheses) & $43.8(128)$ & $51.1(137)$ & $51.9(160)$ & 0.34 \\
\hline Number of inseminations $( \pm$ SEM $)$ & $1.7 \pm 0.5^{\mathrm{a}}$ & $1.9 \pm 0.6^{\mathrm{b}}$ & $2.0 \pm 0.6^{\mathrm{b}}$ & $<0.01$ \\
\hline $\begin{array}{l}\text { Heifers not pregnant by } 73 \text { to } 98 \mathrm{~d} \text { after start of breeding period } \\
(\%, \text { no. in parentheses })\end{array}$ & $9.0^{\mathrm{a}}(324)$ & $14.4^{\mathrm{b}}(243)$ & $15.1^{\mathrm{b}}(239)$ & 0.05 \\
\hline
\end{tabular}

${ }^{\mathrm{a}-\mathrm{c}}$ Within a row, values with different superscripts differ $(P \leq 0.05)$.

${ }^{\mathrm{A}, \mathrm{B}}$ Within a row, values with different superscripts tended to differ $(0.05<P \leq 0.10)$.

${ }^{1} \mathrm{AIE}=(\mathrm{AI}$ at estrus$)$ : heifers received $\mathrm{PGF}_{2 \alpha}$ injections every $11 \mathrm{~d}$ until inseminated or until they were censored; CIDR5 = heifers received a CIDR insert for $5 \mathrm{~d}$, upon CIDR removal heifers received a $\mathrm{PGF}_{2 \alpha}$ injection, and 53 to $60 \mathrm{~h}$ after the $\mathrm{PGF}_{2 \alpha}$ injection heifers received a GnRH injection concomitant with fixed-time AI; and CIDR7 = heifers received a CIDR insert for $7 \mathrm{~d}$, upon CIDR removal heifers received a PGF ${ }_{2 \alpha}$ injection, and 53 to $60 \mathrm{~h}$ after the $\mathrm{PGF}_{2 \alpha}$ injection heifers received a $\mathrm{GnRH}$ injection concomitant with fixed-time AI.

${ }^{2}$ Adjusted hazard ratio.

calculated based on the logistic regression analysis using the intercept and the coefficient estimates from the analysis applied to the formula $P=1 /\left[1+\left(e^{a+b_{1} X_{1}+a+b_{2} X_{2} \cdots}\right)\right]$.

The hazard ratio for pregnancy was analyzed by the Cox proportional hazards regression using the PHREG procedure of SAS, using a backward stepwise multivariate logistic model with variables continuously removed from the model by the Wald statistic criterion if $P>$ 0.10 . The model included treatment and site as fixed effects and the interaction between treatment and site. Furthermore, the effect of treatment on interval from enrollment to establishment of pregnancy was evaluated by survival analysis using the product limit method of the Kaplan-Meier survival analysis of the LITEST procedure of SAS.

Statistical significance was defined as $P \leq 0.05$ and statistical tendencies as $0.05<P \leq 0.10$. Only results of contrasts designed a priori (AIE vs. CIDR5 vs. CIDR7) and conducted within the multivariate ANOVA or logistic regression analyses are reported when the main effect has $P \leq 0.10$.

\section{RESULTS}

\section{Reproductive Performance}

The interval from enrollment to first AI was $(P<$ $0.01)$ affected by treatment. Heifers in the CIDR7 treatment had the longest interval from enrollment to first $\mathrm{AI}$, whereas the interval from enrollment to first $\mathrm{AI}$ did not differ between AIE and CIDR5 heifers (Table $1)$. Heifers in the AIE treatment were most $(P<0.01)$ likely to be pregnant $38 \pm 3 \mathrm{~d}$ after first AI followed by CIDR5 and CIDR7 heifers, respectively (Table 1 ).
Similarly, AIE heifers were most $(P<0.01)$ likely to be pregnant $73 \pm 7 \mathrm{~d}$ after first AI and there was a tendency $(P=0.07)$ for CIDR5 heifers to be more likely to be pregnant $73 \pm 7 \mathrm{~d}$ after first AI than CIDR7 heifers (Table 1). Pregnancy loss was not $(P=0.71)$ affected by treatment (Table 1 ).

Among CIDR5 and CIDR7 heifers, heifers with P4 concentration $\geq 1 \mathrm{ng} / \mathrm{mL}$ on d 0 were $(P=0.03)$ more likely to be pregnant $38 \pm 3 \mathrm{~d}$ after first AI (42.6 vs. $31.3 \%)$. Furthermore, the interaction between treatment and $\mathrm{P} 4$ concentration on d 0 tended $(P=0.09)$ to be associated with percentage of heifers pregnant $38 \pm$ $3 \mathrm{~d}$ after first AI (Figure 2A and Figure 2B). Percentage of heifers pregnant $73 \pm 7 \mathrm{~d}$ after first AI also was $(P=0.03)$ affected by $\mathrm{P} 4$ concentration on $\mathrm{d} 0(\mathrm{P} 4 \geq 1$ $\mathrm{ng} / \mathrm{mL}=41.4$ vs. $\mathrm{P} 4<1 \mathrm{ng} / \mathrm{mL}=29.6 \%)$, but the interaction between treatment and $\mathrm{P} 4$ concentration on d 0 was not $(P=0.14)$ associated with pregnancy $73 \pm$ $7 \mathrm{~d}$ after first AI (Figure 2A).

Interval between first and second $\mathrm{AI}$ was not $(P=$ 0.11 ) affected by treatment. Similarly, the pattern of re-insemination of heifers that were not pregnant after first AI did not $(P=0.98)$ differ among treatments (Figure 3). Percentage of heifers pregnant after the second AI was not $(P=0.34)$ affected by treatment.

Heifers in the AIE treatment had the fewest $(P<$ $0.01)$ number of inseminations during the study but no $(P=0.37)$ differences were observed between CIDR5 and CIDR7 heifers (Table 1). The hazard of pregnancy was greatest $(P<0.01)$ for AIE heifers but it was not $(P=0.12)$ different between CIDR5 and CIDR7 heifers (Table 1). The median days from enrollment to pregnancy were 13, 7, and 27 for AIE, CIDR5, and CIDR7 heifers, respectively. Furthermore, the mean $( \pm$ SEM) days from enrollment to pregnancy were 25.5 


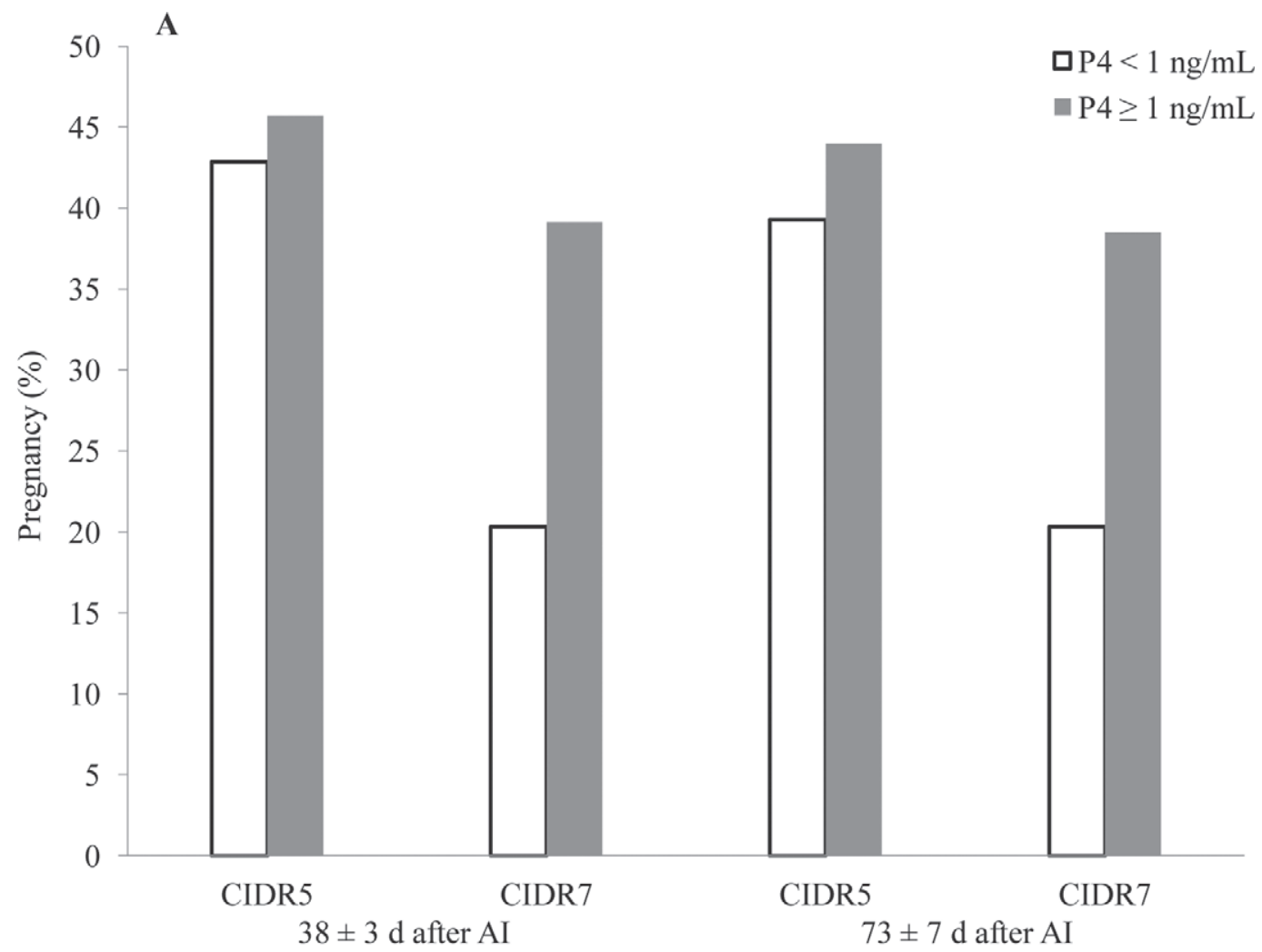

B

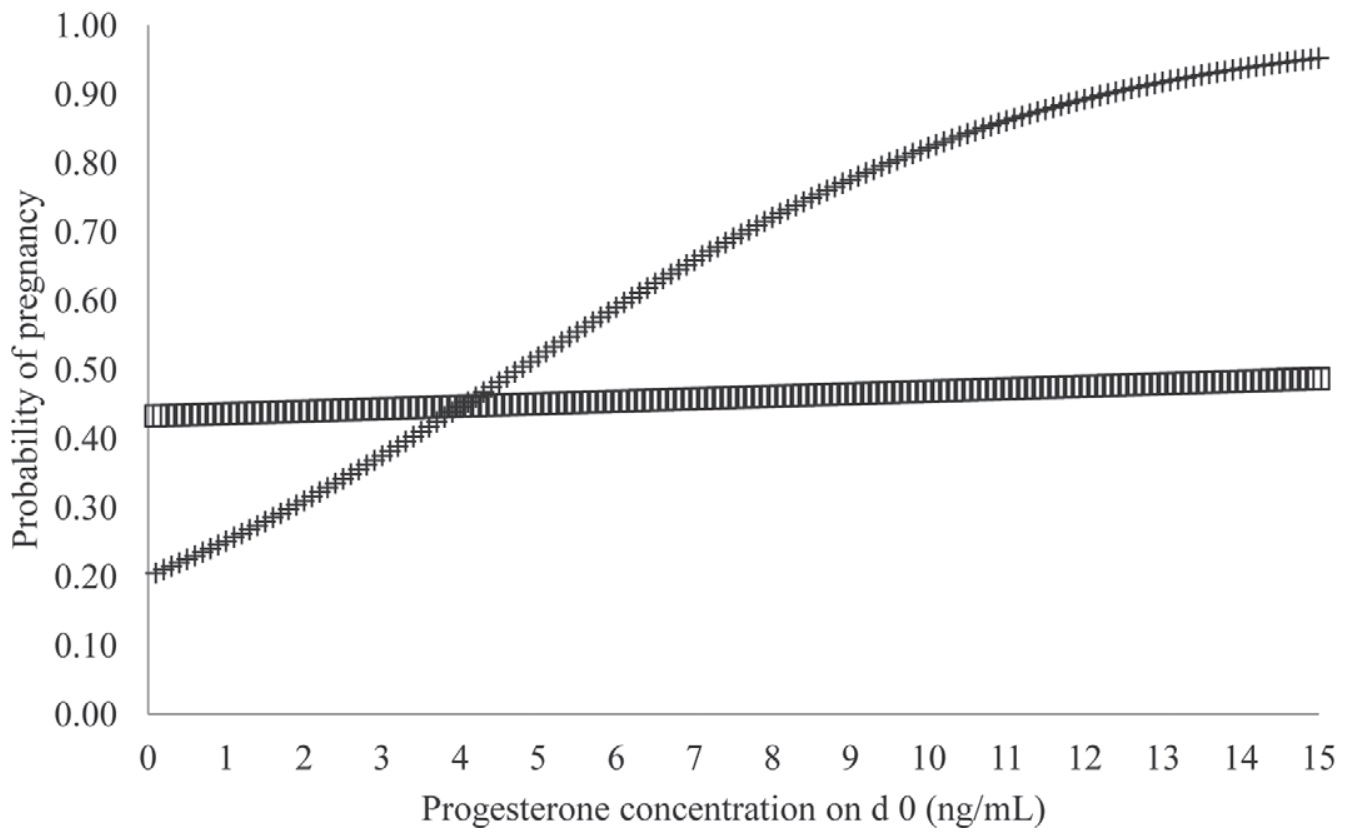

Figure 2. (A) Percentage of heifers pregnant $38 \pm 3$ and $73 \pm 7 \mathrm{~d}$ after first AI according to treatment and classification of progesterone (P4) concentration on d 0. Pregnancy $38 \pm 3 \mathrm{~d}$ after first AI: treatment: $P<0.01$; P4 concentration class on d 0: $P=0.03$; and interaction between treatment and $\mathrm{P} 4$ concentration class on d $0: P=0.09$. Pregnancy $73 \pm 7 \mathrm{~d}$ after first AI: treatment: $P=0.05 ; \mathrm{P} 4$ concentration class on d 0 : $P=0.02$; and interaction between treatment and $\mathrm{P} 4$ concentration class on d $0: P=0.14$. (B) Probability of pregnancy $38 \pm 3 \mathrm{~d}$ after first AI according to P4 concentration on d 0 among CIDR5 ( $\square)$ and CIDR7 (+) heifers. CIDR5 = heifers received a controlled internal drug release (CIDR) insert for $5 \mathrm{~d}$, upon CIDR removal heifers received a $\mathrm{PGF}_{2 \alpha}$ injection, and $53-60 \mathrm{~h}$ after the $\mathrm{PGF}_{2 \alpha}$ injection heifers received a GnRH injection concomitant with fixed-time $\mathrm{AI}$; and $\mathrm{CIDR} 7=$ heifers received a CIDR insert for $7 \mathrm{~d}$, upon $\mathrm{CIDR}_{\text {removal heifers received a PGF }}$ injection, and 53-60 h after the $\mathrm{PGF}_{2 \alpha}$ injection heifers received a $\mathrm{GnRH}$ injection concomitant with fixed-time AI. 


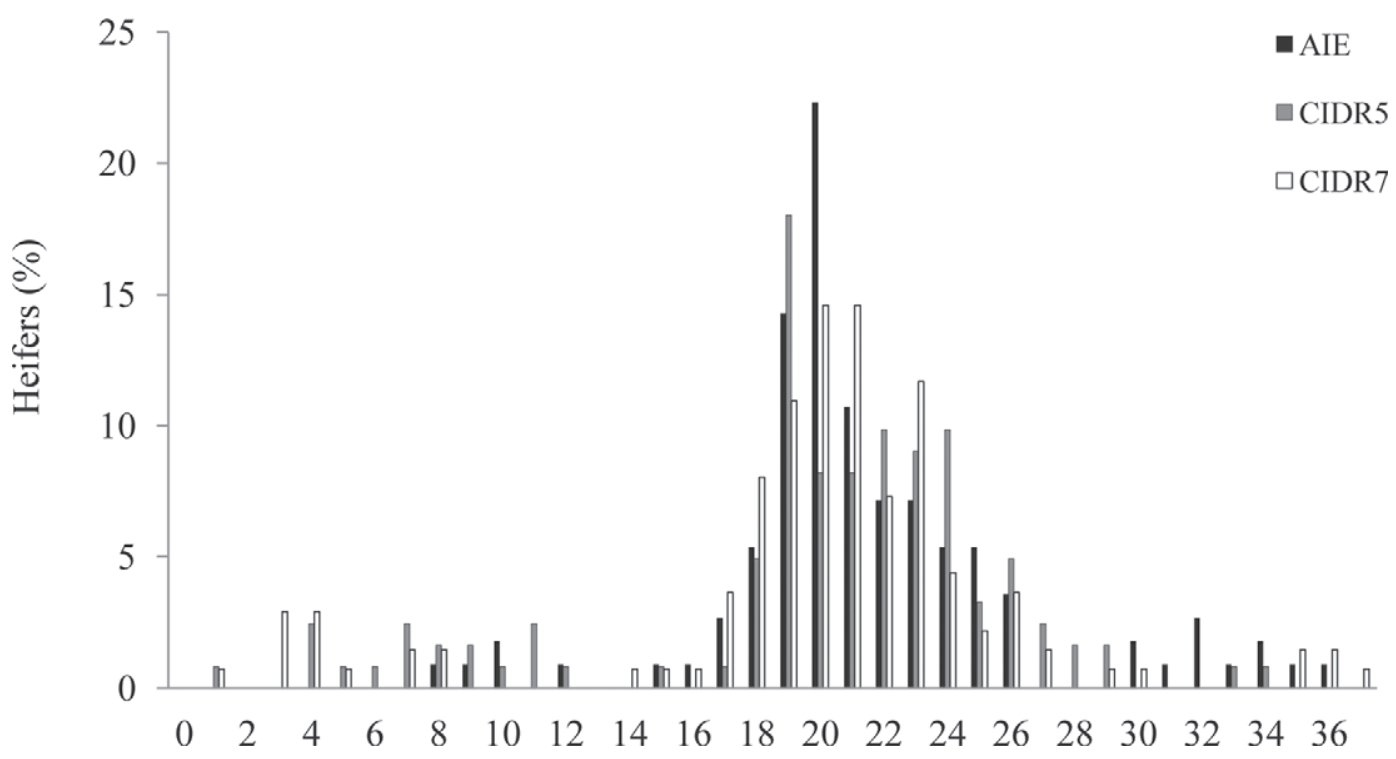

Figure 3. Pattern of reinsemination of heifers not pregnant to first AI. AI at estrus (AIE) $=$ heifers received PGF $2 \alpha$ injections every $11 \mathrm{~d}$ until inseminated or until they were censored; CIDR $5=$ heifers received a controlled internal drug release (CIDR) insert for 5 d, upon CIDR removal, heifers received a $\mathrm{PGF}_{2 \alpha}$ injection, and 53 to $60 \mathrm{~h}$ after the $\mathrm{PGF}_{2 \alpha}$ injection, heifers received a GnRH injection concomitant with fixed-time AI; and CIDR7 $=$ heifers received a CIDR insert for $7 \mathrm{~d}$, upon CIDR removal, heifers received a $\mathrm{PGF}_{2 \alpha}$ injection, and 53 to $60 \mathrm{~h}$ after the PGF $\mathrm{P}_{2 \alpha}$ injection, heifers received a GnRH injection concomitant with fixed-time AI.

$\pm 1.6,32.5 \pm 2.0$, and $36.0 \pm 1.9$ for AIE, CIDR5, and CIDR7 heifers, respectively (Figure 4). Similarly, the percentage of heifers not pregnant at the conclusion of the study was reduced $(P \leq 0.04)$ for AIE heifers compared with CIDR5 and CIDR7 heifers but it was not $(P=0.84)$ different between CIDR5 and CIDR7 heifers (Table 1$)$.

\section{Ovarian Responses}

On d $0, \mathrm{P} 4$ concentration was not $(P=0.34)$ different among treatments (Table 2). Progesterone concentration $(P=0.05)$ and percentage of heifers with $\mathrm{P} 4$ concentration on $\geq 1 \mathrm{ng} / \mathrm{mL}(P<0.01)$ on the day of CIDR removal were greater for CIDR5 than CIDR7 heifers because a greater $(P<0.01)$ percentage of CIDR7 heifers had luteolysis from the day of CIDR insertion to the day of CIDR removal (Table 2). Progesterone concentration on the day of timed AI $(P=$ 0.87 ) and percentage of heifers with $\mathrm{P} 4$ concentration $<1 \mathrm{ng} / \mathrm{mL}$ on the day of timed AI $(P=0.36)$ were not different between CIDR5 and CIDR7 heifers (Table 2). Similarly, the percentage of heifers that had luteolysis between the day of CIDR removal and the day of TAI was not $(P=0.20)$ affected by treatment (Table 2$)$.

\section{Economic Performance}

The cost of the synchronization protocol for first AI was reduced $(P<0.01)$ for AIE heifers compared with
CIDR5 and CIDR7 heifers and, by design, the cost of the synchronization protocols of CIDR5 and CIDR7 heifers was not $(P=1.00)$ different (Table 3$)$. Heifers in the AIE treatment had reduced $(P<0.01)$ cost of semen compared with CIDR5 and CIDR7 heifers, but no $(P=0.37)$ difference between CIDR5 and CIDR7 heifers was observed (Table 3 ). Similarly, cost of rearing AIE heifers was reduced $(P<0.01)$ compared with CIDR5 and CIDR7 heifers but rearing cost of CIDR5 and CIDR7 was not $(P=0.12)$ different (Table 3$)$. Finally, the input cost of AIE heifers was reduced $(P<$ 0.01) compared with that of CIDR5 and CIDR7 heifers but the input costs of CIDR5 and CIDR7 heifers were not $(P=0.26)$ different (Table 3$)$.

\section{DISCUSSION}

In the current experiment, AIE heifers were more likely to become pregnant than heifers submitted to TAI following either the CIDR5 or the CDIR7 protocols. It has been demonstrated previously that AI on spontaneous or $\mathrm{PGF}_{2 \alpha}$-induced estrus results in greater $\mathrm{P} / \mathrm{AI}$ than timed AI following synchronization protocols (Pursley et al., 1997; Stevenson et al., 2008; Rivera et al., 2004). The percentage of heifers pregnant after the CIDR5 protocol was reduced compared with the results reported recently (Rabaglino et al., 2010; Lima et al., 2011). It is important to note that in the current experiment, the interval from $\mathrm{PGF}_{2 \alpha}$ injection to $\mathrm{GnRH}$ injection and timed AI was 53 to $60 \mathrm{~h}$, whereas in the 
Table 2. Effects of $\mathrm{PGF}_{2 \alpha}$-based (AIE) and CIDR-based (CIDR5 and CIDR7) synchronization protocols on progesterone concentration (P4; $\mathrm{ng} / \mathrm{mL}, \pm \mathrm{SEM})$ and ovarian responses $(\%)$ of dairy heifers ${ }^{1}$

\begin{tabular}{|c|c|c|c|c|}
\hline Item & AIE & CIDR5 & CIDR7 & $P$-value \\
\hline P4 on the day of CIDR removal & - & $4.7 \pm 0.3$ & $3.9 \pm 0.3$ & 0.05 \\
\hline Heifers with $\mathrm{P} 4 \geq 1 \mathrm{ng} / \mathrm{mL}$ on the day of CIDR removal & - & 84.9 & 70.4 & $<0.01$ \\
\hline $\mathrm{P} 4$ on the day of timed $\mathrm{AI}$ & - & $0.6 \pm 0.1$ & $0.6 \pm 0.1$ & 0.87 \\
\hline Heifers with $\mathrm{P} 4<1 \mathrm{ng} / \mathrm{mL}$ on the day of timed AI & - & 90.8 & 92.5 & 0.36 \\
\hline $\begin{array}{l}\text { Heifers with luteolysis between the day of } \mathrm{PGF}_{2 \alpha} \text { injection } \\
\text { and the day of timed } \mathrm{AI}^{3}\end{array}$ & - & 91.5 & 95.8 & 0.20 \\
\hline
\end{tabular}

${ }^{1} \mathrm{AIE}=(\mathrm{AI}$ at estrus$)$ : heifers received $\mathrm{PGF}_{2 \alpha}$ injections every $11 \mathrm{~d}$ until inseminated or until they were censored; CIDR5 $=$ heifers received a CIDR insert for $5 \mathrm{~d}$, upon CIDR removal heifers received a $\mathrm{PGF}_{2 \alpha}$ injection, and 53 to $60 \mathrm{~h}$ after the $\mathrm{PGF}{ }_{2 \alpha}$ injection heifers received a GnRH injection concomitant with fixed-time $\mathrm{AI}$; and $\mathrm{CIDR} 7=$ heifers received a CIDR insert for $7 \mathrm{~d}$, upon $\mathrm{CIDR}_{\text {removal heifers received a PGF }}$ injection, and 53 to $60 \mathrm{~h}$ after the $\mathrm{PGF}_{2 \alpha}$ injection heifers received a $\mathrm{GnRH}$ injection concomitant with fixed-time AI.

${ }^{2}$ Heifers were considered to have had luteolysis when P4 on the day of CIDR insertion $\geq 1 \mathrm{ng} / \mathrm{mL}$ and P4 on the day of CIDR removal $<1 \mathrm{ng} / \mathrm{mL}$. ${ }^{3}$ Heifers were considered to have had luteolysis when $\mathrm{P} 4$ on the day of CIDR removal $\geq 1 \mathrm{ng} / \mathrm{mL}$ and $\mathrm{P} 4$ on the day of timed AI $<1 \mathrm{ng} / \mathrm{mL}$.

studies cited previously (Rabaglino et al., 2010; Lima et al., 2011), the interval from $\mathrm{PGF}_{2 \alpha}$ injection to $\mathrm{GnRH}$ injection and timed AI was $72 \mathrm{~h}$. Recently, Bridges et al. (2008) demonstrated that beef cows submitted to a CIDR-based ovulation synchronization protocol that had the proestrus, interval between $\mathrm{PGF}_{2 \alpha}$ injection and $\mathrm{GnRH}$ injection, extended from 60 to $72 \mathrm{~h}$ had greater $\mathrm{P} / \mathrm{AI}$ following timed AI. In the current experi- ment, heifers submitted to the CIDR5 protocol might have benefited from an extended proestrus, because in recent studies with beef cows researchers demonstrated that extended proestrus period resulted in greater concentrations of estradiol before $\mathrm{GnRH}$ induced ovulation (Bridges et al., 2010). The importance of estradiol concentration during the proestrus has been demonstrated by several researchers and is likely to be associated with

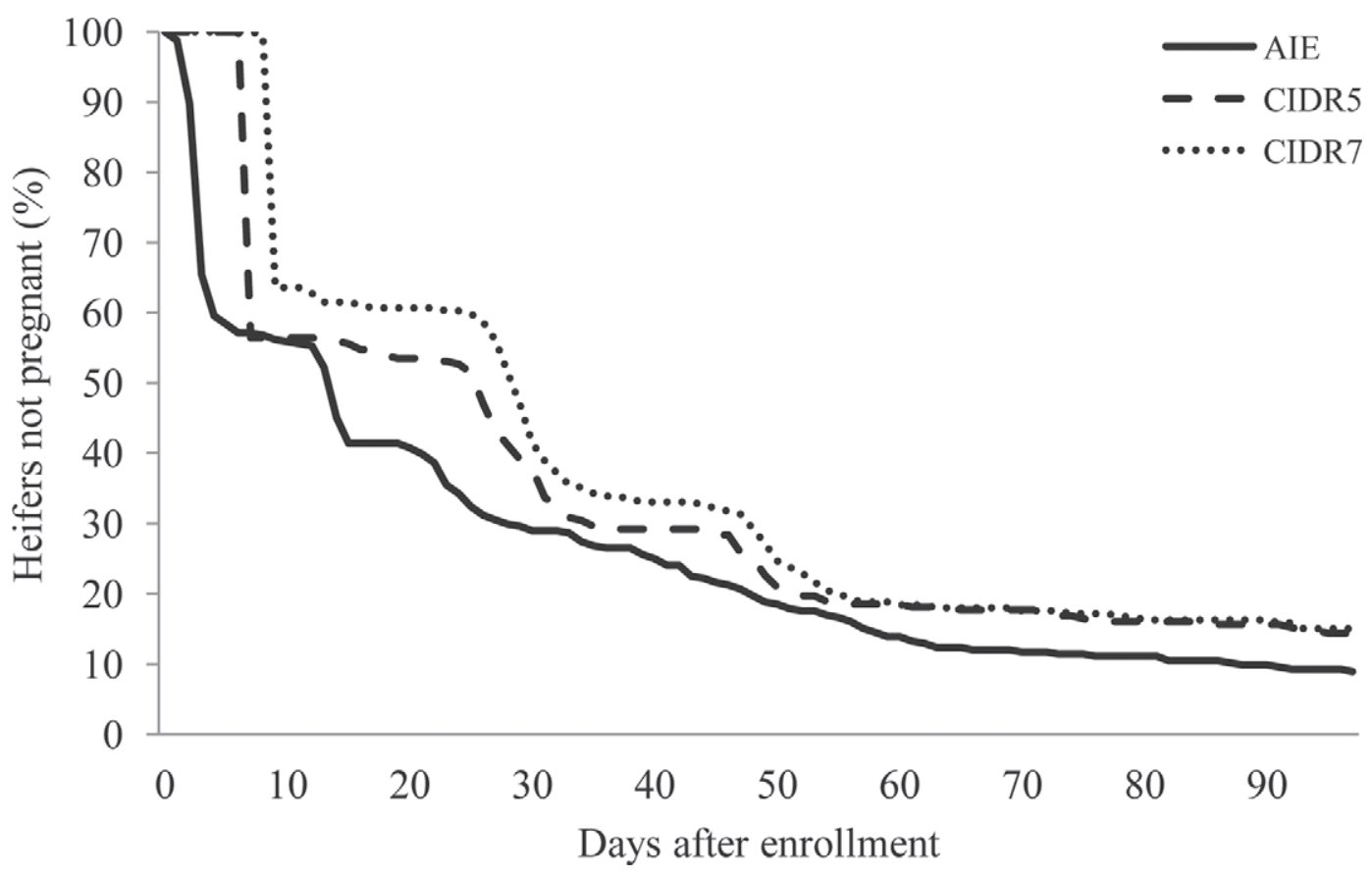

Figure 4. Survival curves for the interval between enrollment and establishment of pregnancy according to treatment. AI at estrus (AIE) $=$ heifers received $\mathrm{PGF}_{2 \alpha}$ injections every $11 \mathrm{~d}$ until inseminated or until they were censored; CIDR5 = heifers received a controlled internal drug release (CIDR) insert for $5 \mathrm{~d}$, upon CIDR removal, heifers received a $\mathrm{PGF}_{2 \alpha}$ injection, and 53 to $60 \mathrm{~h}$ after the PGF P $_{2 \alpha}$ injection, heifers received a GnRH injection concomitant with fixed-time AI; and CIDR7 = heifers received a CIDR insert for 7 d, upon CIDR removal, heifers received a $\mathrm{PGF}_{2 \alpha}$ injection, and 53 to $60 \mathrm{~h}$ after the $\mathrm{PGF}_{2 \alpha}$ injection, heifers received a $\mathrm{GnRH}$ injection concomitant with fixed-time AI. Compared with AIE, the adjusted hazard of pregnancy in CIDR5 and CIDR7 were $0.75(0.63,0.90)$ and $0.65(0.54,0.77)$, respectively. The median and mean $( \pm$ SEM $)$ days to pregnancy were, respectively, AIE $=13$ and $25.5 \pm 1.6$, CIDR $5=7$ and $32.5 \pm 2.0$, and, CIDR7 $=27$ and $36.0 \pm 1.9$. 
Table 3. Economic comparison ( $\$ \neq \mathrm{SEM}$ ) of $\mathrm{PGF}_{2 \alpha}$-based (AIE) and CIDR-based (CIDR5 and CIDR7) synchronization protocols for dairy heifers ${ }^{1}$

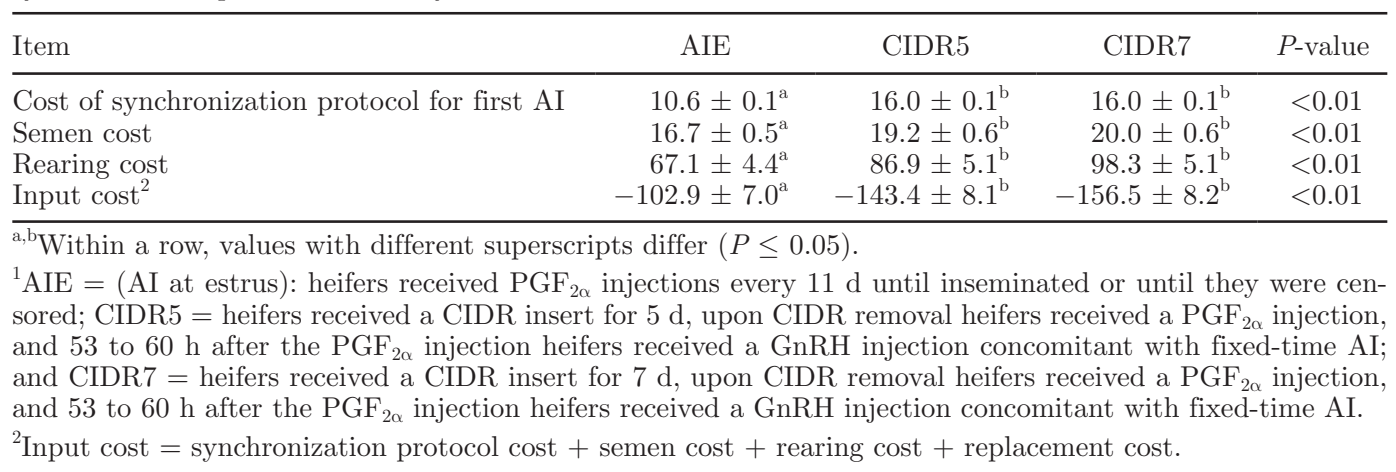

improved fertilization of oocytes (Hawk, 1983; Orihuela and Croxatto, 2001) and reduced incidence of short luteal phase after AI (Bridges et al., 2010). Extending the proestrus period is also expected to result in larger follicles ovulating, formation of larger corpora lutea, and greater concentrations of P4 after AI (Bridges et al., 2008). Thus, it is possible that with an extended proestrus period, CIDR5 heifers could have had greater $\mathrm{P} / \mathrm{AI}$ to first $\mathrm{AI}$ and perhaps not different from AIE heifers. In the current experiment, an interval of 53 to $60 \mathrm{~h}$ was used for convenience and because data demonstrating the benefits of an extended proestrus for dairy heifers submitted to a 5-d CIDR-based synchronization protocol had not been published at the time the current study was conducted. Furthermore, heifers submitted to a 5-d CIDR-based synchronization protocol that received an injection of $\mathrm{GnRH}$ at the start of the protocol and 2 injections of $\mathrm{PGF}_{2 \alpha}, 1$ on $\mathrm{d} 5$ and 1 on $\mathrm{d} 6$, had greater $\mathrm{P} / \mathrm{AI}$ than heifers submitted to the CIDR5 protocol used in the current experiment with an extended proestrus $\left(72 \mathrm{~h}\right.$ from $\mathrm{PGF}_{2 \alpha} / \mathrm{CIDR}$ removal to GnRH/timed AI; Lima et al., 2012).

In the current experiment, $\mathrm{P} / \mathrm{AI}$ of CIDR5 and CIDR7 heifers differed significantly. Extending the length of CIDR treatment by $2 \mathrm{~d}$ likely resulted in prolonged dominance of ovulatory follicles in CIDR7 heifers compared with CIDR5 heifers, which is known to compromise the quality of embryos (Cerri et al., 2009). Furthermore, in the current experiment, CIDR7 heifers were more likely to have luteolysis between CIDR insertion and CIDR removal. It is likely that, because CIDR5 and CIDR7 heifers started CIDR treatment at random stages of the estrous cycle and did not receive a $\mathrm{GnRH}$ injection concomitant with CIDR insertion, the extended CIDR treatment allowed more time for CIDR7 heifers that started the CIDR treatment in mid to late diestrus to have luteolysis before CIDR removal. It has been demonstrated recently in lactating dairy cows that growth of ovulatory follicle under low $\mathrm{P} 4$ concentrations $(<2 \mathrm{ng} / \mathrm{mL})$ results in compromised embryo quality and reduced P/AI (Rivera et al., 2011; Denicol et al., 2012). Therefore, it is likely that CIDR7 heifers had compromised oocyte and embryo quality because of the extended dominance period and growth of follicles under reduced P4 concentrations compared with CIDR5 heifers.

Heifers with $\mathrm{P} 4$ concentration $\geq 1 \mathrm{ng} / \mathrm{mL}$ on the day of CIDR insertion had greater P/AI than those with $\mathrm{P} 4$ concentration $<1 \mathrm{ng} / \mathrm{mL}$ on the day of CIDR insertion. Furthermore, the interaction between treatment and $\mathrm{P} 4$ concentration on the day of CIDR insertion tended to affect $\mathrm{P} / \mathrm{AI} 38 \pm 3 \mathrm{~d}$ after first AI. Such an interaction was observed because the difference in $\mathrm{P} / \mathrm{AI}$ of CIDR5 heifers with $\mathrm{P} 4$ concentration $\geq 1 \mathrm{ng} / \mathrm{mL}$ on the day of CIDR insertion compared with $\mathrm{P} / \mathrm{AI}$ of CIDR5 heifers with $\mathrm{P} 4$ concentration $<1 \mathrm{ng} / \mathrm{mL}$ on the day of CIDR insertion was 2.9 percentage units, whereas the difference in $\mathrm{P} / \mathrm{AI}$ of CIDR7 heifers with $\mathrm{P} 4$ concentration $\geq 1 \mathrm{ng} / \mathrm{mL}$ compared with $\mathrm{P} / \mathrm{AI}$ of CIDR7 heifers with $\mathrm{P} 4$ concentration $<1 \mathrm{ng} / \mathrm{mL}$ on the day of CIDR insertion was 18.8 percentage units. In a recent experiment with lactating dairy cows, no differences were observed in $\mathrm{P} / \mathrm{AI}$ of cows with $\mathrm{P} 4 \geq 1 \mathrm{ng} / \mathrm{mL}$ at the beginning of 8-d or 10-d ovulation synchronization protocols (Santos et al., 2010). However, among cows with $\mathrm{P} 4<1 \mathrm{ng} / \mathrm{mL}$ at the beginning of the ovulation synchronization protocol, P/AI was significantly improved when the length of the ovulation synchronization protocol was reduced by $2 \mathrm{~d}$ (Santos et al., 2010). Reduced concentrations of P4 during follicular waves are associated with increased secretion of LH and concentrations of estradiol (Roberson et al., 1989), premature maturation of oocytes (Inskeep, 2004), abnormal development of embryos at the 8-cell stage (Breuel et al., 1993), and reduced quality of 7-d embryos (Rivera et al., 2011). It is likely, however, that reducing the length of ovulation synchronization 
protocols limits the deleterious effects of reduced P4 concentration and increased concentrations of estradiol on oocyte maturation and embryo quality.

Heifers in the AIE treatment had greater pregnancy rate than CIDR5 and CIDR7 heifers. Pubertal heifers are fertile animals and, as such, the greatest effect of reproductive programs for heifers, particularly pregnancy rate, is dependent on interval to first AI and percentage of heifers that become pregnant to first AI. In the current experiment, pregnancy to first AI was 16.3 to 25.4 percentage units greater for AIE heifers compared with CIDR5 and CIDR7 heifers, respectively. Considering that the average interval from first to second AI and percentage of heifers pregnant to second AI was not different among treatments, the reduced pregnancy to first AI in CIDR5 and CIDR7 heifers had a profound effect on pregnancy rate that was not overcome in subsequent estrous cycles and inseminations.

As expected, the cost of the synchronization protocol was least for AIE heifers, whereas the cost of the synchronization protocols of CIDR5 and CIDR7 heifers were similar. In previous studies with heifers and lactating dairy cows, insemination on spontaneous or $\mathrm{PGF}_{2 \alpha}$-induced estrus resulted in reduced cost of synchronization protocols because of fewer and cheaper pharmaceuticals were used in the synchronization protocols (Stevenson et al., 2008; Chebel and Santos, 2010). The cost of semen was reduced for AIE heifers because these heifers had fewer inseminations while achieving greater pregnancy rates and were more likely to be pregnant at the end of the study. The rearing cost until pregnancy establishment was smallest for AIE heifers, which reflects the fact that AIE heifers had greater pregnancy rates compared with CIDR5 and CIDR7 heifers. Finally, the input cost was smallest for AIE heifers compared with CIDR5 and CIDR7 heifers. The difference in input cost between AIE and CIDR5 heifers was $\$ 36 /$ heifer and that between AIE and CIDR7 heifers was $\$ 49 /$ heifer. The differences in synchronization cost accounted for approximately 12 to $17 \%$ of the difference in input cost, whereas the difference in semen cost accounted for approximately $7 \%$ and the difference in cost of rearing accounted for approximately 55 to $63.7 \%$ of the difference in input cost. This indicates that the most important parameter to determine the synchronization protocol to be used in dairy heifers is pregnancy rate. In a study conducted in Germany, the difference in cost to produce a pregnancy among cows inseminated in estrus compared with cows submitted to a timed AI protocol depended on the estrus detection rate of cows inseminated in estrus (Tenhagen et al., 2004). Pregnancy rate is a function of P/ AI and estrus detection rate. Furthermore, pregnancy rate affects economic return because it affects the speed at which pregnancies are established and percentage of animals that become pregnant. Therefore, the selection of synchronization protocols for heifers has to be made in light of the P/AI, estrus detection rate, and pregnancy rate obtained with the different protocols, with minimal importance given to the cost of such protocols because the latter is very small compared with the rearing cost and replacement cost of nonpregnant heifers. In general, however, the literature (Chebel et al., 2007; Stevenson et al., 2008) and on-farm data (R. C. Chebel and J. C. Dalton; unpublished data) suggest that $\mathrm{PGF}_{2 \alpha}$-based estrus synchronization protocols are very efficient and economically viable for dairy heifers, if effective and accurate estrus detection is in place.

\section{CONCLUSIONS}

Ovulation synchronization protocols for dairy heifers have improved significantly in the past $5 \mathrm{yr}$, particularly with the advent of the 5-d CIDR-based synchronization protocol. Data from the current experiment and from other research groups indicate that ovulation synchronization protocols for heifers should have a 5 -d CIDR treatment and a proestrus (interval from $\mathrm{PGF}_{2 \alpha}$ and timed AI) of approximately $72 \mathrm{~h}$. Nonetheless, in herds with appropriate estrus detection efficiency and accuracy and with appropriate personnel and facilities for daily estrus detection, $\mathrm{PGF}_{2 \alpha}$-based estrus synchronization protocols are expected to be cost effective.

\section{REFERENCES}

Ahmadzadeh, A., D. Gunn, J. B. Hall, and B. Glaze. 2010. Evaluation of 5-day versus 7-day CIDR treatment on reproductive outcomes of beef heifers using a modified timed-AI protocol. J. Anim. Sci. 88(Suppl. 1):394. (Abstr.)

Breuel, K. F., P. E. Lewis, F. N. Schirck, A. W. Lishman, E. K. Inskeep, and R. L. Butcher. 1993. Factors affecting fertility in the postpartum cow: Role of the oocyte and follicle in conception rate. Biol. Reprod. 48:655-661.

Bridges, G. A., L. A. Helser, D. E. Grum, M. L. Mussard, C. L. Gasser, and M. L. Day. 2008. Decreasing the interval between GnRH and $\mathrm{PGF}_{2 \alpha}$ from 7 to 5 days and lengthening proestrus increases timedAI pregnancy rates in beef cows. Theriogenology 69:843-851.

Cerri, R. L. A., H. M. Rutigliano, R. C. Chebel, and J. E. P. Santos. 2009. Period of dominance of the ovulatory follicle during synchronization programs influences embryo quality. Reproduction 137:813-823.

Chebel, R. C., F. A. Braga, and J. C. Dalton. 2007. Factors affecting reproductive performance of Holstein heifers. Anim. Reprod. Sci. 101:208-224.

Chebel, R. C., F. S. Guagnini, J. E. P. Santos, J. P. Fetrow, and J. R. Lima. 2010. Sex-sorted semen for nulliparous heifers: Effects on reproductive and lactational performances. J. Dairy Sci. 93:2496-2507.

Chebel, R. C., and J. E. P. Santos. 2010. Effect of inseminating cows in estrus following a presynchronization protocol on reproductive and lactation performances. J. Dairy Sci. 93:4632-4643.

Denicol, A. C., G. Lopes Jr., L. G. D. Mendonça, F. A. Rivera, F. Guagnini, R. V. Perez, J. R. Lima, R. G. S. Bruno, J. E. P. Santos, and R. C. Chebel. 2012. Low progesterone concentration during 
the development of the first follicular wave reduces pregnancy per insemination of lactating dairy cows. J. Dairy Sci. 95:1794-1806.

Hawk, H. W. 1983. Sperm survival and transport in the female reproductive tract. J. Dairy Sci. 66:2645-2660.

Inskeep, E. K. 2004. Preovulatory, postovulatory, and postmaternal recognition effects of concentrations of progesterone on embryonic survival in the cow. J. Anim. Sci. 82(E-Suppl.):E24-E39.

Lima, F. S., H. Ayres, M. G. Favoreto, R. S. Bisinotto, L. F. Greco, E. S. Ribeiro, P. S. Baruselli, C. A. Risco, W. W. Thatcher, and J. E. P. Santos. 2011. Effects of gonadotropin-releasing hormone at initiation of the 5-d timed artificial insemination (AI) program and timing of induction of ovulation relative to $\mathrm{AI}$ on ovarian dynamics and fertility of dairy heifers. J. Dairy Sci. 94:4997-5004.

Lima, F. S., E. S. Ribeiro, R. S. Bisinotto, N. Martinez, L. F. Greco, K. N. Galvão, C. A. Risco, W. W. Thatcher, M. Amstalden, and J. E. P. Santos. 2012. Effects of GnRH and administering number of PGF2 $\alpha$ doses in the 5-d timed AI program on ovarian responses and fertility of dairy heifers. J. Dairy Sci. 95(Suppl. 2):576.

NAHMS. 2007. Breeding practices. Pages 13-16 in Dairy 2007, Part IV: Reference of Dairy Cattle Health and Management Practices in the United States. United States Department of Agriculture, Washngton, DC.

NRC. 2001. Nutrient Requirements of Dairy Cattle. 7th ed. Natl. Acad. Press, Washington, DC.

Orihuela, P. A., and H. B. Croxatto. 2001. Acceleration of oviductal transport of oocytes induced by estradiol in cycling rats is mediated by nongenomic stimulation of protein phosphorylation in the oviduct. Biol. Reprod. 65:1238-1245.

Pursley, J. R., M. C. Wiltbank, J. S. Stevenson, J. S. Ottobre, H. A Garverick, and L. L. Anderson. 1997. Pregnancy rates per artificial insemination for cows and heifers inseminated at a synchronized ovulation or synchronized estrus. J. Dairy Sci. 80:295-300.

Rabaglino, M. B., C. A. Risco, M. J. Thatcher, I. H. Kim, J. E. P. Santos, and W. W. Thatcher. 2010. Application of one injection of prostaglandin $\mathrm{F}_{2 \alpha}$ in the five-day Co-Synch+CIDR protocol for estrous synchronization and resynchronization of dairy heifers. J. Dairy Sci. 93:1050-1058.

Rivera, F. A., L. G. D. Mendonça, G. Lopes Jr., R. V. Perez, F. Guagnini, M. Amstalden, R. G. S. Bruno, J. E. P. Santos, and R. C. Chebel. 2011. Low progesterone concentration during superstimulation of the first follicular wave impairs embryo quality of lactating dairy cows. Reproduction 141:333-342.
Rivera, H., H. Lopez, and P. M. Fricke. 2004. Fertility of Holstein dairy heifers after synchronization of ovulation and timed AI or AI after removed tail chalk. J. Dairy Sci. 87:2051-2061.

Rivera, H., H. Lopez, and P. M. Fricke. 2005. Use of intravaginal progesterone-releasing inserts in a synchronization protocol before timed AI and for synchronizing return to estrus in Holstein heifers. J. Dairy Sci. 88:957-968.

Rivera, H., R. A. Sterry, and P. M. Fricke. 2006. Presynchronization with gonadotropin-releasing hormone does not improve fertility in Holstein heifers. J. Dairy Sci. 89:3810-3816.

Roberson, M. S., M. W. Wolfe, T. T. Stumpf, R. J. Kittok, and J. E. Kinder. 1989. Luteinizing hormone secretion and corpus luteum function in cows receiving two levels of P4. Biol. Reprod. 41:997-1003.

Santos, J. E. P., C. D. Narciso, F. Rivera, W. W. Thatcher, and R. C. Chebel. 2010. Effect of reducing the period of follicle dominance in a timed AI protocol on reproduction of dairy cows. J. Dairy Sci. 93:2976-2988

Sartori, R., J. M. Haughian, R. D. Shaver, G. J. M. Rosa, and M. C. Wiltbank. 2004. Comparison of ovarian function and circulating steroids in oestrous cycles of Holstein heifers and lactating cows. J. Dairy Sci. 87:905-920

Schmitt, E. J., T. Diaz, C. M. Barros, R. L. de la Sota, M. Drost, E. W. Fredriksson, C. R. Staples, R. Thorner, and W. W. Thatcher. 1996. Differential response of the luteal phase and fertility in cattle following ovulation of the first-wave follicle with human chorionic gonadotropin or an agonist of gonadotropin-releasing hormone. J. Anim. Sci. 74:1074-1083.

Stevenson, J. L., J. C. Dalton, J. E. P. Santos, J. A. Rodrigues, F. A Braga, S. Bitente, and R. C. Chebel. 2008. Effect of breeding protocols and reproductive tract score on reproductive performance of dairy heifers and economic outcome of breeding programs. J. Dairy Sci. 91:3424-3438.

Tenhagen, B. A., M. Drillich, R. Surholt, and W. Heuwieser. 2004 Comparison of timed AI after synchronized ovulation to AI at estrus: Reproductive and economic considerations. J. Dairy Sci. $87: 85-94$.

Vasconcelos, J. L. M., R. W. Silcox, G. J. M. Rosa, J. R. Pursey, and M. C. Wiltbank. 1999. Synchronization rate, size of the ovulatory follicle, and pregnancy rate after synchronization of ovulation beginning on different days of the estrous cycle in lactating dairy cows. Theriogenology 52:1067-1078. 